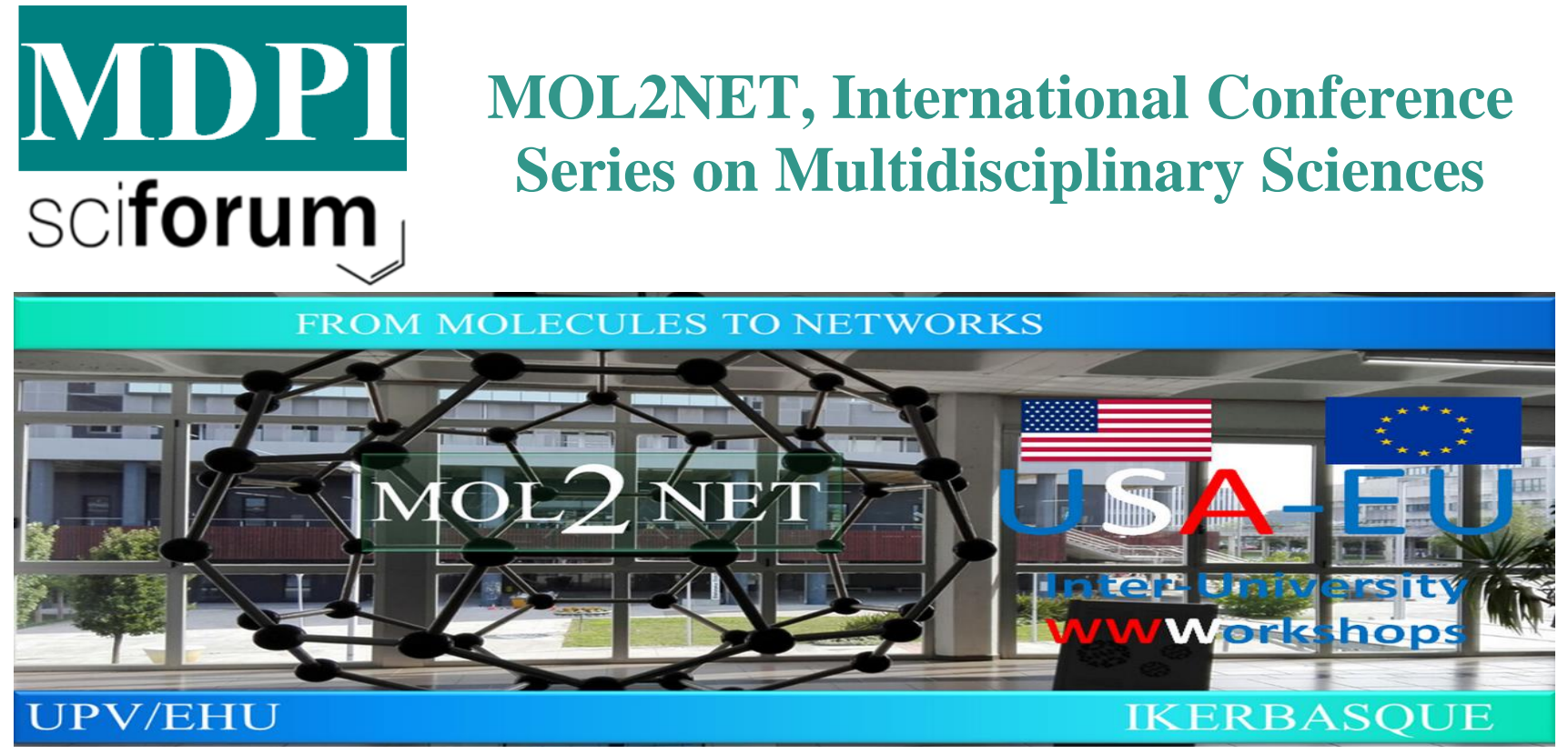

\title{
Pharmacobotanical study of aerial vegetative organs of Senna splendida (Leguminosae): a species of ethnomedicinal interest
}

\author{
Flávio Sousa Souto $^{a}$, Edinalva Alves Vital dos Santos ${ }^{b}$, Anauara Lima e Silva ${ }^{c} \&$ \\ Maria de Fátima Agra ${ }^{d}$
}

${ }^{a}$ Programa de Pós-graduação em Biologia Vegetal, Centro de Ciências Biológicas, Universidade Federal de Pernambuco, Recife (PE) Brasil.

${ }^{b}$ Programa de Pós-graduação em Botânica, Departamento de Biologia, Universidade Federal Rural de Pernambuco, Recife, Brasil.

${ }^{c}$ Programa de Pós-graduação em Produtos Naturais e Sintéticos Bioativos, Centro de Ciências da Saúde, Universidade Federal da Paraíba, João Pessoa, Brasil.

${ }^{d}$ Laboratório de Taxonomia e Farmacobotânica, Departamento de Biotecnologia, Universidade Federal da Paraíba, João Pessoa, Brasil.

\begin{abstract}
.
Senna splendida (Vogel) H.S.Irwin \& Barneby (Leguminosae) is a ethnomedicinal species native to Brazil, popularly known in the country as "fedegoso-grande and "feijão-brabo", it is used against kidney diseases, bronchitis, rheumatism, anemia and inflammations. A pharmacobotanical study of the aerial vegetative organs of $S$. splendida was carried out, looking for morphoanatomical data that can contribute to the taxonomy and quality control of its ethno-drugs. Paradermic sections of both epidermal surfaces and cross sections of the leaf and stem were made freehand. Histochemical tests were also performed to indicate the types of plant metabolites. Senna splendida is a sub-shrubby to shrubby, with cylindrical stems, leaves with 4-leaflets, sub-cylindrical petiole, leaflet blade are oblong
\end{abstract}


https://mol2net-07.sciforum.net/

or narrowly ovate, and carthaceous. In transverse section, the stem has the vascular system syphonostelic, ectophloic, continuous, consisting of a single circular vascular bundle, and a welldeveloped medullary parenchyma. The vascular system is collateral in the rachis, petiole, and midrib; the petiole and midrib showed four main bundles and two accessories; and the leaf rachis showed a main bundle and two accessories. The leaflet epidermis is hypostomatic, which has sinuous anticlinical cell walls on the both surfaces with anisocytic and paracytic stomata. The mesophyll is dorsi-ventral with a single-palisade, and 4-5-seriate spongy parenchyma. Inorganic idioblasts druse-type and prismatic crystals were observed near de vascular system of rachis, leaflet midrib, and petiole. Histochemical tests indicated the presence of starch, structural and non-structural phenolic compounds, alkaloids, and proteins in various parts of the leaflets, and also in the stem. The pharmacobotanical study of Senna splendida provided subsidies for its taxonomy and, in addition, it contributed to the quality control of its ethno-drugs and, thus, expanded the anatomical knowledge for the genus Senna. Financial support: CNPq and CAPES.

Keywords: Cassia, Ethnobotany, Fabaceae, Medicinal plant.

\section{References}

Albuquerque, U.P., Medeiros, P.M., Almeida, A.L.S., Monteiro, J.M., Lins Neto, E.M. F., Melo, J.G., Santos, J.P., 2007. Medicinal plants of the caatinga (semi-arid) vegetation of NE Brazil: a quantitative approach. Journal of ethnopharmacology 114(3), 325-354. https://doi.org/10.1016/j.jep.2007.08.017

Almeida, C.F.C.B.R., Silva, T.D.L., Amorim, E.L.C., Maia, M.D.S., Albuquerque, U.P., 2005. Life strategy and chemical composition as predictors of the selection of medicinal plants from the caatinga (Northeast Brazil). Journal of arid environments 62(1), 127-142. https://doi.org/10.1016/j.jaridenv.2004.09.020

Flora do Brasil em construção (2020). Senna. Jardim Botânico do Rio de Janeiro. Available at: http://floradobrasil.jbrj.gov.br/reflora/floradobrasil/FB23149 (acessed 26 october 2021)

Irwin, H.S., Barneby, R.C., 1982. The American Cassiinae a synoptical revision of Leguminosae tribe Cassieae subtribe Cassiinae in the New World. Memoirs of the New York Botanical Garden 35(1), 1-454.

Rodrigues, V.E.G., Carvalho, D.D., 2001. Levantamento etnobotânico de plantas medicinais no domínio do cerrado na região do Alto Rio Grande - Minas Gerais. Ciência e Agrotecnologia 25(1), 102-123.

Trentin, D.S., Giordani, R.B., Zimmer, K.R., Silva, A.G., Silva, M.V., Correia, M.T.S., Baumvol, I.J.R., Macedo, A.J., 2011. Potential of medicinal plants from the Brazilian semi-arid region (Caatinga) against Staphylococcus epidermidis planktonic and biofilm lifestyles. Journal of Ethnopharmacology 137(1), 327-335. https://doi.org/10.1016/j.jep.2011.05.030 